\title{
Impact assessments of radioactive discharges into rivers: Application to the appraisal of the Chernobyl dyke project on the Pripyat river
}

\author{
S. Lepicard
} Centre d'Étude sur l'Évaluation de la Protection dans le Dornaine Nucléaire (CEPN),
BP. 48, 92263 Fontenay-aux-Roses, France

\begin{abstract}
The rise of the water level of the Pripyat river and the erosion associated with ice-jam events lead to the periodic inundation of the contaminated plain surrounding the Chernobyl power plant. This results in the resuspension and dissolution of radioactive particles and their discharge into the Pripyat and Dnieper waters. This re-contamination of the Dnieper cascade is a significant source of exposure for the Ukrainian population living along the river. To reduce this radiological impact, a project of construction of a dyke on the right bank of the Prypiat river was elaborated. This paper gives an appraisal of this project. In a first phase, the estimated collective dose reduction associated with the construction of the dyke is presented. Then, the construction and maintenance costs of the dyke, as well as the expected benefits associated with dose reduction, are evaluated. The cost-benefit ratios which can be calculated on this basis are around unit, which tends to show that the benefits associated with the construction of the dyke would just compensate the construction and maintenance costs of the project. Taking account of the positive side effects on various sectors of the economy, this project would globally positively contribute to improve the living conditions of the Ukrainian population in a long term perspective.
\end{abstract}

\section{INTRODUCTION - CONTEXT OF THE STUDY}

The rise of the water level of the Pripyat river - particularly during spring flooding - as well as erosion associated with ice-jam events, lead to the periodic inundation of the plain surrounding the Chernobyl power plant. The immersion of contaminated ground results in the re-suspension and dissolution of radioactive particles which were deposited at the time of the accident in 1986 and which are still present in the upper layers of the soil.

The radioactivity eroded from the flood plain, where the density of radioactive contamination remains extremely high - the ground contamination can reach values around $17,000 \mathrm{kBq} \cdot \mathrm{km}^{-2}$ for ${ }^{90} \mathrm{Sr}$ and around $36,000 \mathrm{kBq} \cdot \mathrm{km}^{-2}$ for ${ }^{137} \mathrm{Cs}$-, is then released into the Pripyat river and enters the Dnieper river through the Kiev reservoir. This radioactivity is then transported through the Dnieper down to the Black Sea (Figure 1.1). This secondary re-contamination of the Dnieper is a significant source of exposure for the Ukrainian population living along the river.

To reduce this radiological impact, the construction of a dyke on the right bank of the Prypiat river close to the Chernobyl power plant was proposed to complement an already existing protective dyke built in 1993 on the left bank. In order to provide elements for evaluating the pertinence and effectiveness of this project, Bonnard \& Gardel Consulting Engineers Ltd. (BG) - Lausanne, Switzerland - and the CEPN have been awarded a contract by the Geneva office of the United Nations to perform an evaluation study. In this context, the CEPN performed the dose assessment as well as the cost-benefit analysis [1]. 


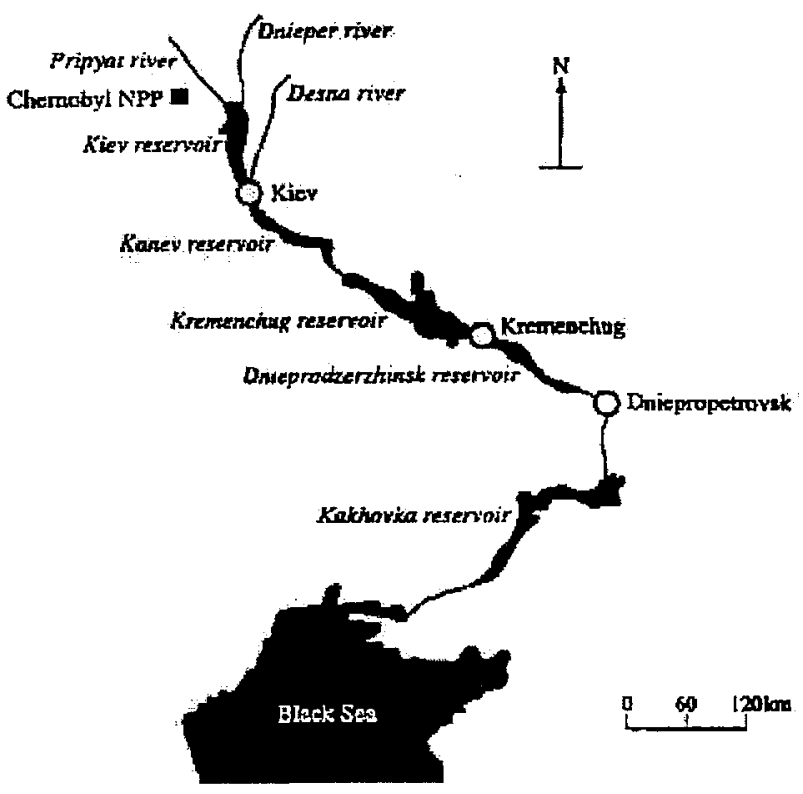

Figure 1.1 : The Dnieper cascade

\section{COMPUTERIZATION OF THE DOSE-ASSESSMENT MODELLING}

\subsection{Modelling of radionuclides transport into rivers}

Collective dose assessments were performed with RIPARIA, a "box-modelling" computer code for assessing the radiological consequences of radioactive releases into rivers. This code was developed and tested by CEPN for the French Rhône river [2], and its parameters were adjusted to better cope with the specificity of the Dnieper cascade. The modelling of the sedimentation processes was modified for this study, on the basis of the European methodology developed at the European level [3].

The major assumptions inherent to this box modelling are the homogeneity of each box with respect to its parameters (i.e. suspended sediment load, sedimentation rate, depth, etc.), and an equal distribution of the activity within the volume of the box. Exchanges between boxes are expressed in terms of an average annual transferred volume of water. Seasonal variations (of water flows for example) are not considered in the modelling. The impacts of such seasonal variations of water flows were estimated and considered in the sensitivity analysis on key parameters of the model.

The Dnieper river-reservoirs system is made up of six large artificial reservoirs: Kiev, Kanev, Kremenchug, Dnerprodzerdzin, Zaporozhye and Kakhov. The Pripyat and the Dnieper rivers are the main tributaries of the Kiev reservoir. Each reservoir is modelled as a box made up of different layers. The first layer corresponds to the water column. The processes of dispersion of the radionuclides into the river system refers to mechanisms of transport by water exchanges between each compartment (water outflow). The second layer corresponds to the bed sediments. The sediment processes result from three phenomena: depletion of suspended materials in equilibrium with the water phase activity, diffusion of radioactivity between the water column and the bed sediment layer, and bioturbation, modelled as a diffusive process between layers too (Figure 2.1). 


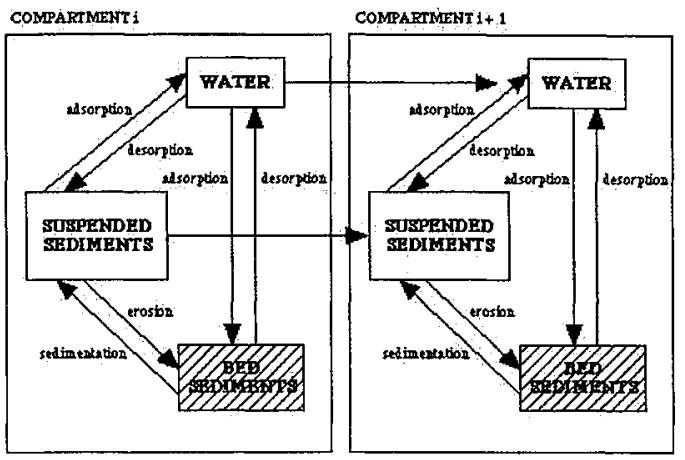

Figure 2.1 : Modelling of the radionuclide dispersion and sedimentation processes

Detailed equations of the time evolution of the activity concentration in both water columns and bed sediment layers for each compartment are given in [1]. Activity in the water column is lost to bed sediments through diffusion and sorption onto suspended particulates which then settle out. Part of the sediment activity returns to water column through diffusion and bioturbation processes.

Collective doses are calculated for different routes of exposure on the basis of the time-integrated activity concentration in unfiltered water. The routes of exposure considered in the calculations were the direct consumption of water and fish from the successive Dnieper reservoirs, the ingestion of food products irrigated with the Dnieper water (green and root vegetables, cereals) as well as milk produced on irrigated pastures. A multiplying factor of 0.5 was applied to activity concentrations for water consumption and fish ingestion, to take into account filtering processes for « drinking water » and the edible fraction of fish for « fish consumption ».

The adjustment of sedimentation parameters was performed making comparisons between predicted values from RIPARIA code and from another computer code for river dispersion modelling (WATOX), developed by a Ukrainian institute [5]. The results were also compared with measurements performed into the Kiev reservoir between 1987 and 1993 (Figure 2.2). Results from RIPARIA appear to be quite conservative in the different reservoirs of the Dnieper cascade, nonetheless they remain in average in a rather good accordance with measurements and with WATOX results. The observed differences can be partly explained by the fact that seasonal variations of water flows are not taken into account in the RIPARIA modelling (but taken into account in WATOX), keeping in mind that these water flow variations can reach a factor about 3 within on year in the Kiev reservoir for example.

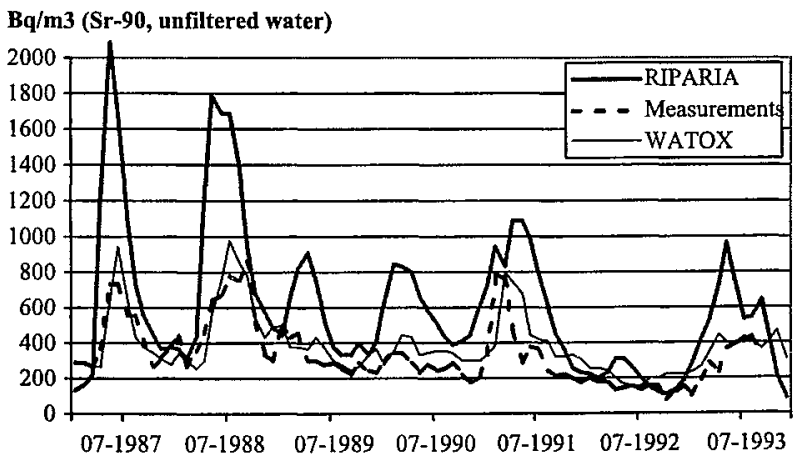

Figure 2.2 : Comparison between predicted and measured ${ }^{90} \mathrm{Sr}$ activities in the Kiev reservoir during the period 1987-1993 


\subsection{Water usage and agricultural data}

A compilation of data from different sources [6], [7] was performed, with some major assumptions to cope with the structure of the dose module of RIPARIA, to estimate the exposure of the population through the usage of the Dnieper waters. A synthesis of the agricultural and consumption data considered in the present study is given in Tables 2.1 and 2.2.

Table 2.1 : Irrigated surfaces of agricultural land

\begin{tabular}{|l||c|c|c|c|c|}
\hline Reservoir & $\begin{array}{l}\text { Irrigated areas of } \\
\text { agricultural land }\end{array}$ & $\begin{array}{c}\text { Irrigated areas of } \\
\text { pastures } \\
\text { (cow milk) } \\
\text { (ha) }\end{array}$ & $\begin{array}{c}\text { Irrigated areas of } \\
\text { green vegetables }\end{array}$ & $\begin{array}{c}\text { Irrigated areas of } \\
\text { root vegetables }\end{array}$ & $\begin{array}{c}\text { Irrigated areas of } \\
\text { cereals }\end{array}$ \\
\hline Kieva) & (ha) & (ha) \\
\hline Kanev & $5.80 \times 10^{4}$ & $2.90 \times 10^{4}$ & $5.80 \times 10^{5}$ & $1.16 \times 10^{4}$ & $1.16 \times 10^{4}$ \\
\hline Kremenchug & $1.80 \times 10^{4}$ & $2.90 \times 10^{4}$ & $5.80 \times 10^{3}$ & $1.16 \times 10^{4}$ & $1.16 \times 10^{4}$ \\
\hline Dneprod. & $8.50 \times 10^{5}$ & $8.95 \times 10^{4}$ & $1.79 \times 10^{4}$ & $3.58 \times 10^{4}$ & $3.58 \times 10^{4}$ \\
\hline Zaporozhe & $8.50 \times 10^{4}$ & $4.25 \times 10^{4}$ & $8.50 \times 10^{3}$ & $1.70 \times 10^{4}$ & $1.70 \times 10^{4}$ \\
\hline Kakhovka & $1.40 \times 10^{6}$ & $4.25 \times 10^{4}$ & $8.50 \times 10^{3}$ & $1.70 \times 10^{4}$ & $1.70 \times 10^{4}$ \\
\hline
\end{tabular}

Table 2.2 : Population, water consumption and fish catches in the Dnieper cascade

\begin{tabular}{l|c|c|c|c|}
\hline Reservoir & $\begin{array}{c}\text { Total population in } \\
\text { the Dnieper basin }\end{array}$ & $\begin{array}{c}\text { Population consuming } \\
\text { water from the Dnieper } \\
\text { cascade }\end{array}$ & $\begin{array}{c}\text { Consumption of } \\
\text { water } \\
\left(\mathbf{m}^{3} \cdot \mathbf{y}^{-1}\right)\end{array}$ & Fish catches \\
\hline Kiev & $2.25 \times 10^{6}$ & $3.75 \times 10^{5}$ & $2.05 \times 10^{5}$ & $1.16 \times 10^{6}$ \\
\hline Kanev & $2.25 \times 10^{6}$ & $3.75 \times 10^{5}$ & $2.05 \times 10^{5}$ & $1.16 \times 10^{6}$ \\
\hline Kremenchug & $4.40 \times 10^{6}$ & $9.00 \times 10^{5}$ & $4.93 \times 10^{5}$ & $2.79 \times 10^{6}$ \\
\hline Dniprod. & $1.27 \times 10^{7}$ & $3.40 \times 10^{6}$ & $1.86 \times 10^{5}$ & $1.05 \times 10^{7}$ \\
\hline Zaporozhe & $1.30 \times 10^{6}$ & $7.00 \times 10^{5}$ & $3.83 \times 10^{5}$ & $2.17 \times 10^{6}$ \\
\hline Kakhovka & $8.20 \times 10^{6}$ & $2.50 \times 10^{6}$ & $1.37 \times 10^{5}$ & $7.75 \times 10^{6}$ \\
\hline \hline
\end{tabular}

\subsection{Results: collective dose reduction}

Dose calculations were performed for a reference time period of 70 years of operation of the dyke. 1,000 sequences of flooding events during this 70 year reference time period were produced by $B G$ with a Monte-Carlo simulation. From this, 9 sequences were retained for dose calculations (most probable events, worst and best scenarios included), leading to annual inputs of ${ }^{137} \mathrm{Cs}$ and ${ }^{90} \mathrm{Sr}$ into the Kiev reservoir from the dissolution and the erosion of the contaminated flood plain.

The dose reduction associated with the construction of the right bank dyke ranges from 150 to 300 man.Sv for the considered 70 -year period, for a population of about 8 to 10 millions people. Depending on the considered sequence, from $28 \%$ to $52 \%$ of the total dose reduction over 70 years can be reached during the first 20 years, which means that the benefit of the dyke reaches about $50 \%$ of its total value within the 20 first years.

A sensitivity analysis on key parameters of dose calculation model was performed. This led to estimate the variability of the collective dose results to a factor 6 approximately. Furthermore, it should be noted that, due to the lack of pertinent information, this result does not take into account the reduction in the recontamination due to the contaminated materials buried after the Chernobyl accident in the flood plain. As a consequence, the global effectiveness of the dyke is underestimated. 


\section{COST - BENEFIT ANALYSIS}

The costs of the dyke were respectively expressed as "one-off" costs for the construction phase and as annual costs for the maintenance during the considered 70-year operation period. Construction cost and annual maintenance costs were estimated at 630,000 US\$ and 50,000 US\$. $y^{-1}$ respectively.

As far as this project was dealing with long term protection investments, it was necessary to take a discount rate into account. The discount rates to be considered depend on the country (based on the financial market) and on the type of investment. In France, the value retained by the "Commissariat Général au Plan" was $8 \%$ in 1992, ranging from 8 to $10 \%$ within the period 1970-1992 [8], while lower values were used in other countries. Finally, values of $5 \%$ and $8 \%$ were respectively considered in this study [9] [10] and applied to operating and maintenance costs of the dyke.

For the evaluation of the expected benefit, a basic monetary value of the man-sievert was estimated, derived from the Ukrainian gross domestic product in 1997. An adjustment of this basic value was proposed, based on recent theoretical developments in the monetary valuation of the man-sievert for public exposure [9] [11]. The resulting value is about 8,400 US $\$$ per man-sievert. Given the estimated dose reduction (from 150 to 300 man.Sv), that led to estimate the benefit of the dyke in the range of 1.26 to 2.52 millions US\$.

Finally, the cost-benefit ratios were calculated, given the construction and maintenance costs of the dyke and the monetary value of the collective dose reduction associated with the construction of the dyke. The results range from 0.5 to 1.2 (Table 3.1 ).

Table 3.1 : Economic valuations of costs and benefit of the dyke

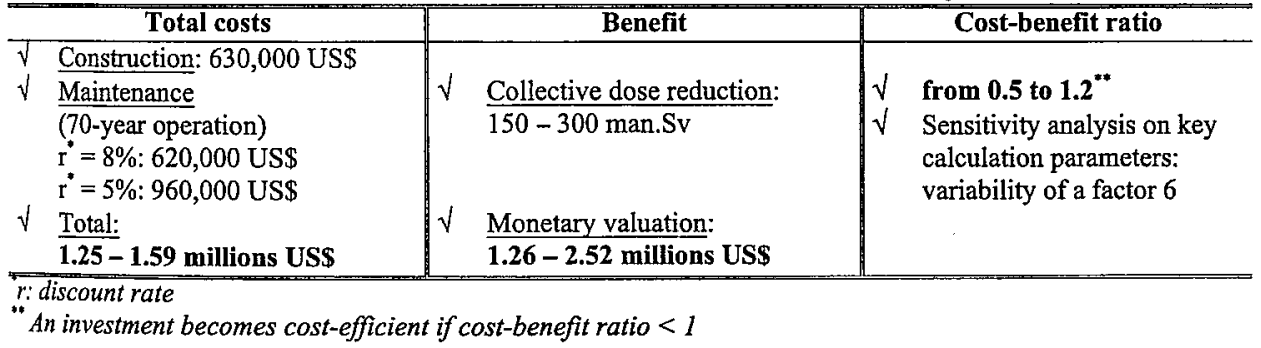

\section{CONCLUSION}

Considering only radiological and economic criteria, and based on the available information and adopted assumptions - which were rather conservative -, the expected benefits associated with the construction of the right bank dyke would tend to just compensate the estimated construction and maintenance costs of the project.

Complementarily, taking into account positive side effects of the dyke on the various sectors of the economy, this project, which was initiated more than 12 years after the accident, would be an effective means to improve the radiological situation and the global living conditions of the Ukrainian population in a long term perspective. 


\section{References}

[1] S. Lepicard, Chernobyl dyke on the Pripyat river: collective dose reduction and cost-benefit analysis, CEPN Report $N^{\circ} 265,1999$.

[2] D. Raffestin, S. Lepicard, P. Michou, RIPARIA : Logiciel d'évaluation de l'impact radiologique associé au relâchement de matières radioactives en milieu fluvial, Rapport $C E P N N^{\circ} 237,1995$.

[3] European Commission, Methodology for assessing the radiological consequences of routine releases of radionuclides to the environment, RP 72, EUR 15760, 1995.

[4] S. Lepicard, D. Raffestin, POSEIDON 3.0 - Logiciel pour l'évaluation des impacts radiologiques en milieu marin, $C E P N-L-99 / 2,1999$.

[5] M. Zheleznyak, T. Shepeleva, V. Sizonenko, I. Mezhueva, Simulation of countermeasures to diminish radionuclide fluxes from the Chernobyl zone via aquatic pathways, Radiation Protection Dosimetry, Vol.73, N¹-4, 181-186, 1997.

[6] V. Berkovski, G. Ratia, O. Nasvit, Internal doses to Ukrainian populations using Dnieper river water, Health Physics, Vol.71, Nº1, 37-44, 1996.

[7] V. Berkovski, O. Voitsekhovitch, O. Nasvit, M. Zheleznyak, U. Sansone, Exposures from aquatic pathways, In: Proceedings of the first international conference on the radiological consequences of the Chernobyl accident, EUR 16544 EN, 1996.

[8] C. Schieber, T. Schneider, L. Eeckhoudt, Valeurs monétaires de l'homme.sievert et prise en compte du temps, Rapport $C E P N N^{\circ} 214,1993$.

[9] C. Lefaure, The man-sievert value: concept, models status and practices, European Commission/International Atomic Energy Agency ALARA Training Course, Prague, 1997.

[10] C. Gollier, Discounting an uncertain future, GREMAQ and IDEI, University of Toulouse - France, 1997.

[11] L. Eeckhoudt, C. Schieber, T. Schneider, P. Godfroid, Monetary value of the man.sievert for public exposure versus worker exposure, CEPN Report $N^{\circ} 262,1999$. 